\title{
Effect of Porphyromonas gingivalis infection on leukocyte count in rat model of diabetes mellitus
}

\author{
Safira Niza Ulfita*, Agustin Wulan Suci Dharmayanti ${ }^{* *}$, Budi Yuwono*** \\ *Dentistry Study Program, Faculty of Dentistry, Universitas Jember, East Java, Indonesia \\ ${ }^{* * B}$ Biomedical Department, Faculty of Dentistry, Universitas Jember, East Java, Indonesia \\ *** Oral Surgery Department, Faculty of Dentistry, Universitas Jember, East Java, Indonesia \\ *JI Kalimantan No 37, Jember, East Java, Indonesia; e-mail: agustinwulan.fkg@unej.ac.id
}

Submitted: $17^{\text {th }}$ March 2017; Revised: $2^{\text {nd }}$ August 2017; Accepted: $21^{\text {st }}$ November 2017

\begin{abstract}
Diabetes mellitus (DM) is a metabolic disorder characterized by hyperglycemia and become the third cause of death in Indonesia. The most common oral complications occured in DM is periodontitis. Porphyromonas gingivalis $(P g)$ is the main etiology of periodontitis, one of periodonthopathogen relate to systemic disease. However this theory still controversial, DM and periodontitis have the same pathogenesis, thus are cellular changes. $P g$ is predicted affect the total leukocytes count in DM. The aim of this study was to determine the effect of $P g$ infection to total leukocytes count in DM rat model. The rat model of DM was obtained by injection of streptozotocin with different dosage for 5 days sequentially then injected by $P g$ on distobuccal and distopalatal sulcus of the maxillary first molars for 19 days with interval 3 days. The total leukocytes were calculated manually by Neubauer improved cell counting chamber. The results demonstrated that rat model of DM which injected by $P g$ has the lowest total leukocytes count. Therefore, $P g$ infection decreased the total leukocytesin DM rat model
\end{abstract}

Keywords: diabetes mellitus; leukocytes; periodontitis; Porphyromonas gingivalis

\section{INTRODUCTION}

Diabetes mellitus (DM) is carbohydrate, fat and protein metabolism disorder characterized by hyperglycemia, and it is the third leading cause of death in Indonesia at $6.7 \% .^{1,2,3}$ Prolonged hyperglycemia conditions leads to cellular and inflammatory changes in oral cavity, one of which is periodontitis. Some researchers have revealed an association between DM and periodontitis, both of which have almost the same pathogenesis but unclear interrelation. ${ }^{4,5,6}$

The association of DM and periodontitis was related to the dysregulation of the natural immune system by increasing leukocyte infiltration. Moreover it causes a decrease in the number of systemic leukocytes therefore the body is susceptible to infection. In addition, DM increase the number of leukocytes and trigger activation of the immune system in periodontal tissue through enhancement of proinflammatory cytokines production associated with periodontal tissue destruction. ${ }^{3,7}$ While periodontitis are thought to exacerbate DM conditions through inflammation and systemic infection by periodontopathogen, one of Porphyromonas gingivalis $(\mathrm{Pg})$. $^{8.9}$

Periodontitis is a complex and multifactorial periodontal inflammation of the tissues, mainly due to periodontopathogen, one of which is $P g .^{10,11} \mathrm{It}$ is frequently associated with certain systemic diseases because bacteria and their products spread systemically to other tissues. ${ }^{12,13}$ Epidemiological studies also report that $P g$ might aggravate DM complications. ${ }^{14}$

This study was aimed to determine the effect of $P g$ infection in DM using leukocytes count indicator because leukocytes revealed individual health degree and the severity of disease. ${ }^{15,16}$ The enhancement of leukocytes count can be utilized as an infection parameter, especially due to bacteria, while the deprivation of leukocytes count 
is contributed as viral infections, drug use, and leukemia. ${ }^{2,17}$

Cellular changes occurred in DM and periodontitis are not similar. In DM, there is developed an increase of leukocyte infiltration impacted to reduction leukocytes count, while in periodontitis there is enhancement of leukocytes count. ${ }^{3,18}$ Heretofore, previous studies only revealed effect periodontitis to DM epidemiologically. Accordingly this study performed in vivo experimental study by means of animal models in order to demonstrate influence of $\mathrm{Pg}$ infection to leukocytes count in rat model periodontitis.

\section{MATERIALS AND METHODS}

This research has been approved by the Ethics and Advocacy Commission, Faculty of Dentistry Universitas Gadjah Mada 00967/KKEP/FKGUGM/EC/2017 to be taken place in Biomedical Laboratorium Faculty of Dentistry, University of Jember. This study was a experimental study with only the post test control group design. ${ }^{19}$ This study used 16 healthy male wistar rats (Rattus norvegicus), 3 months old and body weight $200-250$ grams. Rats were divided into 4 groups. They were control group (K), $P g$ injection as group 1 (P1), streptozotocin induction (DM group) as group 2 (P2), DM group injected $P g$ as group 3 (P3). Before treatment, those rats were acclimatized for a week for adaptation to places and foods. The rats were fed with standard pellet AD2 (Comfeed, Indonesia) 30 grams per day with mineral water (Aqua, Indonesia) $50 \mathrm{ml}$.

The exposure agents used for the treatment group obtained $2 \times 10^{9} \mathrm{CFU} / \mathrm{ml} \mathrm{Pg}$ ATCC 33277 (0.5 $\mathrm{\mu g} / 0.05 \mathrm{ml} \mathrm{PBS})$ to induce periodontitis and streptozotocin (Bioworld, USA) to stimulate DM. The $P g$ culture medium was prepared by dissolving 3.7 grams of Brain Heart Infusion Agar (BHI-A) and $100 \mathrm{ml}$ of aquades in erlemeyer tube, and it was homogenized. Subsequently, the tube was sealed using cotton and sterilized in autoclave (Memmert, Germany) at $121^{\circ} \mathrm{C}$ for 15 minutes. The sterile $\mathrm{BHI}-\mathrm{A}$ was mixed with $10 \mu \mathrm{l}$ vitamin $\mathrm{K}$, and it was added $50 \mu \mathrm{l}$ hemin $(50 \mathrm{mg}$ hemin in $100 \mathrm{ml}$ aquades and $1 \mathrm{ml} \mathrm{NaOH}$ ) and $500 \mu \mathrm{l}$ yeast extract and then homogenized. Afterwards, it was poured in petridish about $25 \mathrm{ml} /$ petridish until solid. Subsequently, Pg was inoculated on these mediums. After that, these medium were incubated into decycator for $2 \times 24$ hours. The preparation of $P g$ suspension was performed after $P g$ has been cultured using Brain Heart Infusion Borth (BHI-B). $\mathrm{BHI}-\mathrm{B}$ medium contained mixture of 0.37 gram $\mathrm{BHI}-\mathrm{B}$ in $10 \mathrm{ml}$ aquadest in tube. Next the tube was sealed with cotton and sterilized in autoclave at 121 ${ }^{\circ} \mathrm{C}$ for 15 minutes. The sterile $\mathrm{BHI}-\mathrm{B}$ was added 1 $\mu \mathrm{l}$ vitamin $\mathrm{K}, 5 \mu \mathrm{l}$ hemin and $50 \mu \mathrm{l}$ yeast extract, and then it was homogenized. The $P g$ suspension in $\mathrm{BHI}-\mathrm{B}$ was prepared in order to made $\mathrm{Pg}$ colony. ${ }^{20}$ Streptozotocin stock solution was derived from streptozotocin powder dissolved with aquadest, and then it was dropped with $0.1 \mathrm{M}$ citrate buffer solution until streptozotocin solution reach $\mathrm{pH} 4.5$. Next it was homogenized by vortex and stored at $4{ }^{\circ} \mathrm{C} .{ }^{21}$

On the other hand, the control group (K) was without treatment. Rats in group 1 (P1) was injected with $0.05 \mathrm{ml} \mathrm{Pg}$ in the distopalatal sulcus and the distobuccal of the upper first molar about 7 times with 3 days intervals for 19 days. The $P g$ concentration utilized in this study was $0.5 \mu \mathrm{g} / 0.05$ ml PBS. ${ }^{20}$ The group 2 (P2) and 3 (P3) performed hyperglycemic by streptozotocin, as diabetogenic agent, with stratified dosages. The stratified dosages were started $40 \mathrm{mg} / \mathrm{kg} \mathrm{BW}$ at the first day, $35 \mathrm{mg} / \mathrm{kgBW}$ at the second day, $30 \mathrm{mg} / \mathrm{kgBW}$ at the third day, $25 \mathrm{mg} / \mathrm{kg} \mathrm{BW}$ at the fourth day and $20 \mathrm{mg} / \mathrm{kg} \mathrm{BW}$ at the fifth day. Streptozotocin was performed intraperitoneally, previously the injection area was disinfectant by alcohol spray. Afterwards, the injection was smeared by povidone iodine. ${ }^{21}$ On the sixth day, P3 group was injected with $0.05 \mathrm{ml} P g$ ATCC 33277 with concentration of $2 \times 10^{9} \mathrm{CFU} / \mathrm{ml}$ in the area the distobuccal and distopalatal gingival sulcus of the maxillary first molars. Injection was performed 7 times at 3-day intervals for 19 days. ${ }^{20}$ During the treatment, the blood glucose levels of rats were observed by blood sampling from the vein tail using glucometer (Easy Touch, Taiwan). The diabetic rats were signed blood glucose level more than $300 \mathrm{mg} / \mathrm{dll}^{21}$ The blood glucose level observation in the P1 group was performed on the 2nd, 4th, 7th and 14th days during 19 days 
of treatment periods as well as on the day before termination. The blood glucose level observation in P2 group was performed every streptozotocin injection for five days and the day before termination. The blood glucose level observation in P3 group was performed every streptozotocin injection for five days. Subsequently, the observations were on the 2nd, 4th, 7th and 14th days for 19 days of $P g$ injection and the day before termination. Body weight of animal models was observed at the same time as the blood glucose level examination. After completed treatment in each group, the rats were incubated for a day before they were terminated.

Blood sampling was taken from intracardiac blood. The rats were anesthetized until they were unconscious before their blood was taken and collected on a tube with EDTA addition. Leukocyte counting was done manually using the improved neubauer booth count (Assistent, Germany). The number of leukocytes per $\mathrm{mm}^{3}$ was calculated following the formula: ${ }^{22}$
Total number of leukocyte $=50 \times \mathrm{N}$ Equation 1) $\mathrm{N}=$ number of leukocytes contained in all four squares

The resulted data was then tested statistically using Kruskall-Wallis test.

\section{RESULTS}

The results demonstrated that the highest average of leukocytes count was in the group of P2, DM model group, while the lowest average of leukocytes count was in P3 group of DM rat model injected with $\mathrm{Pg}$. Table 1 revealed that the $\mathrm{P} 2$ group has the highest average leukocyte count of $13,232 / \mathrm{mm}^{3}$ and the P3 group has the lowest average of $4,738.90 / \mathrm{mm}^{3}$. Besides it, the average of leukocytes count in the control group $(K)$ was higher than that in the $\mathrm{P} 1$ group and $\mathrm{P} 3$ groups. The Kruskall-Wallis statistical tests of the result revealed that the Chi square was 6,079 with significance 0,108 . This indicated no significant difference.

Table 1. Average and standard deviation of total number of leukocytes

\begin{tabular}{lccccc}
\hline \multicolumn{1}{c}{ Group } & $\mathrm{K}$ & $\mathrm{P} 1$ & $\mathrm{P} 2$ & $\mathrm{P} 3$ \\
\hline $\mathrm{x} \pm \mathrm{SD}\left(\mathrm{mm}^{3}\right)$ & $12.908,50 \pm 1.409,79$ & $12.208,38 \pm 4.799,05$ & $13.232 \pm 2.638,42$ & $4.738,90 \pm 3.207,94$ \\
\hline $\mathrm{K}$ & $:$ Control group & & & \\
$\mathrm{P} 1$ & $:$ Treatment group 1 $(\mathrm{Pg}$ injection) & & \\
$\mathrm{P} 2$ & : Treatment group 2 (DM mouse model) & & \\
$\mathrm{P} 3$ & : Treatment group 3 (DM mouse model then injected with $\mathrm{Pg})$ & &
\end{tabular}

\section{DISCUSSION}

The statistical analysis of this study revealed there were no significant differences. It was suggested that the sample of this study was inadequate or the theory utilized in this study has not been analyzed in many studies. Furthermore, the blood sampling for leukocytes count was performed once during the study, a day after treatment. This was presumably able to influence statistic analysis which showed insignificant result. Concomitant during present study, there was a dead rat of DM rat model injected with $P g$ (P3 group).

The DM model in present study demonstrated the highest average of leukocytes count. This was presumed hyperglycemia stimulated immune system activation by increasing the leukocytes count. DM induced insulin resistance caused by chronic inflammation and immune system activation. Proinflammatory cytokines, especially interleukin-6 (IL-6), are potent stimulants of leukocyte differentiation, so as IL-6 was affected enhancement of leukocytes count and insulin resistance. Furthermore, the immune system activation could escalate leukocytes count and cytokine production accompanied by decrease of insulin sensitivity. ${ }^{7}$ The relationships between leukocytes and DM might be associated with various proinflammatory cytokine actions. Some inflammatory markers, such as IL-6, TNF- $\alpha$ and CRP, are related with DM. TNF- $\alpha$ are played a role in inflammation of DM through an interaction insulin signaling pathway and function of $\beta$-cell. This relationship might be correlated to granulocytes secreting TNF- $\alpha$. A polymorphism of IL-6 gene might be also related with the total 
count and differential leukocytes because IL-6 was produced by mononuclear cells. In other words, the leukocyte count related with DM. ${ }^{23}$

An increase of leukocytes count in DM was associated with worsening glucose metabolism. The mechanism regarding the escalation was insulin resistance. Disturbance of insulin action in adipose tissue, muscle, and liver leads to chronic low-grade inflammatory conditions. Both intraarterial inflammation and extravascular stimulation could induce the secretion of proinflammatory cytokines generating in leukocyte differentiation and maturation. Each process associated with chronic inflammation exhibited deprivation of insulin action and insulin resistance which could enhance inflammation. ${ }^{24}$ Several previous studies also revealed there was an increase of leukocytes count as following increase of the metabolic syndrome component in diabetic patients. ${ }^{25}$

$P g$ injected DM models group showed the lowest leukocytes count. This was suggested that $P g$ worsened DM condition through immune system deterioration marked by deprivation of leukocytes count. This condition tent to cause an infection, particularly bacterial infection, and then it induced sepsis through bacteremiaemia.. ${ }^{26,27}$ The sepsis in this group might be associated with a decrease leukocytes count. Moreover, hyperglycemia caused leukocyte capability (chemotaxis and phagocytosis), notably neutrophil and monocyte deteriorated. However, the diapedesis ability of leukocytes from blood vessel to tissue enhanced. In addition, virulence factors of $P g$, especially gingipain and LPS, diminished production of proinflammatory cytokines and enhanced vascular permeability. The enhancement of vascular permeability exacerbated the leukocyte deprivation in peripheral blood vessels, enhancement of leukocyte migration and leukocyte accumulation into the tissues, as well as increase of bacteraemia. ${ }^{26-30}$

This present study exhibited the average of leukocyte count in the $P g$-injected group was lower than in control group. This result was differed with the previous studies revealed that continuously $\mathrm{Pg}$ injection enhanced leukocytes count. Because LPS produced $P g$ directly triggered the host response. LPS stimulated leukocytes action in order to release various cytokines, such as IL-1 $1 \beta$, TNF- $\alpha$, IL-6, PGE2 and MMPs. $P g$ and its products entered the bloodstream and caused systemic infections. The host responded by increasing the number of leukocyte cells in the bloodstream as a defense against $P g \cdot{ }^{31}$ Moreover, the $P g$ virulence factors released protease enzymes reducing the function of the intercellular endothelial junctional cadherin and platelet endothelial cell adhesion molecule. The virulence factors also enhanced permeability of vascular endothelial and gingival epithelium. The permeability enhancement led $P g$ penetration easily and entering the bloodstream. However, as a consequence there was enhancement of leukocyte migration from blood vessels to peripheral tissues. Thus aforesaid was suggested as a cause of leukocytes count in the $\mathrm{Pg}$ group lower than control group. ${ }^{28}$

The average of leukocytes count in the control group was higher than the normal value. We suggested it was linked to stressful conditions in animal models stimulating an increase of leukocytes count. One of the etiologies of leukocytosis is stress. ${ }^{32}$ Persistent stress conditions induce nerve fibers to secrete noradrenaline hormone into the blood vessels. This neurotransmitter signal subsequently intensifies hematopoietic stem cells proliferation impacted leukocytes count enhancement. ${ }^{33}$ Another factor suggested stimulating excessive leukocyte count more than the normal level represented human error which leukocytes and diluents was not mixed homogenously. It led undistributed leukocytes well. Aforementioned, it is necessary to undertake further studies about observation and figuring total leukocytes regarding periods interval therefore we are qualified to know obviously leukocytes profile alteration.

\section{CONCLUSION}

On the basis of this study, it is conclusive that $P g$ exposure decreases the total number of leukocytes in DM rat model. 


\section{ACKNOWLEDGEMENT}

The researchers would like to extent gratitude to the Student Activity Program - Research Grant of the Ministry of Research, Technology and Higher Education of the Republic of Indonesia with number 117/B31/KM/2016 dated February 19, 2016.

\section{REFERENCES}

1. Ngugi MP, Njagi JM, Kibiti CM, Ngeranwa JJN, Njagi ENM. Diagnosis of diabetes mellitus. Int $\mathrm{J}$ of Diabetes Research. 2012; 1(2): 24 - 27.

2. Kementerian Kesehatan RI. www.depkes.go.id. 2006; [diakses pada 3 Agustus 2016].

3. Graves DT, Kayal RA. Diabetic complication and dysregulated innate immunity. Front Biosci National Institutes of Health. 2011; 13: 1227 - 1239.

4. Stanko P, Holla LI. Bidirectional association between diabetes mellitus and inflammatory periodontal disease: a review. Biomed Pap Med Fac Univ Palacky Olomouc Czech Repub. 2014; 158(1): $35-38$.

5. Preshaw PM, Alba AL, Herrera D, Jepsen $\mathrm{S}$, Konstantinidis A, Makrilakis K, Taylor R. Periodontitis and diabetes: a two-way relationship. Diabetologia. 2011; 55: 21 - 31.

6. Deshpande K, Jain A, Sharma RK, Prashar S, Jain R. Diabetes and periodontitis. J Indian Soc Periodontol. 2010; 14(4): 207 - 212.

7. Vozarova, B, Weyer C, Lindsay RS, Pratley RE, Bogardus C, Tataranni C. High white blood cell count is associated with a worsening of insulin sensitivity and predicts the development of type 2 diabetes. Diabetes Journal. 2002; 51: $455-461$.

8. Mealey BL. Periodontal disease and diabetes a two-way street. JADA. 2006; 139(3): 252.

9. Igari K, Kudo T, Toyofuku T, Inoue Y, Iwai T. Association between periodontitis and development of systemic disease [Internet]. Oral Biology and Dentistry; 2014 [diakses pada 3 Agustus 2016]. Tersedia dari http://www. hoajonline.com/oralbioldent/2053-5775/2/4.
10. Grenier D, Tanabe S. PG gingipains trigger a proinflammatory response in human monocytederived macrophages through the p38a mitogenactivated protein kinase signal transduction pathway [Internet].2010[diakses pada 2 Agustus 2016]. Tersedia dari www.mdpi.com/journal/ toxin.

11. How KY, Song KP, Chan KG. Porphyromonas gingivalis: an overview of periodontopathic pathogen below the gum line. Front in Micro. 2016; 7: 53 .

12. Mysak J, Podzimek T, Sommerova P, Lyuya-Mi Y, Bartova J, Janatova T, Prochazkova J, Duskova J. Review article Porphyromonas gingivalis: major periodontopathic pathogen view. Journal of Immunology Research: Hindawi Publishing Corperation. 2014; 2014: 1 - 8 .

13. Carvalho-Filho PC, Gomes-Filho IS, Meyer R, Olczak T, Xavier MT, Trindade SC. Role of $P G H m u Y$ in immunopathogenesis of chronic periodontitis. Journal Mediators of Inflammation. 2016; 2016(1): 1 - 9 .

14. Laheij AMGA, Loveren CV, Deng D, Soetde JJ. The impact of virulence factors of $P G$ on wound healing in vitro. Journal of Oral Microbiology. 2015; 7(10): 1 - 8.

15. Ates $\mathrm{AH}$, Canpolat $\mathrm{U}$, Yorgun $\mathrm{H}$, Kaya EB, Sunman H, Demiri E, Taher A, Hazirolan T, Aytemir K, Tokgözoglu L, Kabakçi G, Oto A. Total white blood cell count is associated with the presence, severity and extent of coronary atherosclerosis detected by dual-source multislice computed tomographic coronary angiography. Cardiol J. 2011; 18(4): 371 - 377.

16. Leng $S X$, Xue $Q$, Huang $Y$, Ferrucci L, Fried LP, Walston JD. Baseline total and specific differential white blood cell counts and 5 year all causemortality in community-dwelling older women. Exp. Gerontol. 2005; 40: 982 - 987.

17. Riley LK, Rupert J. Evaluation of patients with leukocytosis. American Family Physician. 2015; 92(11): 1004 - 1011

18. Al-Rasheed A. Elevation of white blood cells and platelet counts in patients having chronic 
periodontitis. Saudi Dental Journal: Elsevier. 2012; 24(1): $17-21$.

19. Notoatmodjo S. 2010. Metodologi Penelitian Kesehatan. Jakarta: Rineka Pustaka: 33 - 34.

20. Kusumawardani B. Dampak infeksi $P G$ pada jaringan periodontal maternal terhadap pertumbuhan janin: analisis pengaruh ekspresi TLR-2, TLR-4, TNF, IL-10 dan caspase-3 pada plasenta tikus terhadap penurunan berat plasenta, berat janin, dan panjang janin. Disertasi. Yogyakarta: Universitas Gadjah Mada; 2012.

21. Hikmah N, Shita ADP, Maulana H. Rat diabetic blood glucose level profile with stratified dosage streptozotocin (SD-STZ) and multi low dosage streptozotocin (MLD-STZ) induction methods. The Journal of Tropical Life Science. 2015; 5(1): $30-34$.

22. Chakravarti, Bhattacharya. A Handbook of Clinical Pathology. Academic Publisher; 2005: $5-7$.

23. Borné Y, Smith JG, Nilsson PM, Melander O, Hedblad B, Engström G. Total and differential leukocyte counts in relation to incidence of diabetes mellitus: a prospective populationbased cohort study. PLoS ONE Journal. 2016; $1-13$.

24. Jiang H, Yan WH, Li CJ, Wang AP, Dou JT, Mu YM. Elevated white blood cell count is associated with higher risk of glucose metabolism disorders in middle-aged and elderly chinese people. International Journal of environment Reseacrh Public Health. 2014; 11(5): 5497 - 5509.

25. Shim WS, Kim HJ, Kang ES, Ahn CW, Lim SK, Lee HC, Cha BS. The association of total and differential white blood cell count with metabolic syndrome in type 2 diabetic patients. Diabetes Research and Clinical Practice. 2006; 73: $284-291$.
26. Hirasawa H, Shigeto Oda, Masataka Nakamura. Blood glucose control in patients with severe sepsis and septic shock. World J Gastroenterol. 2009; 15(33): 4132 - 4136.

27. Koh GC, Peacock SJ, van der Poll T, Wiersinga WJ. The impact of diabetes on the pathogenesis of sepsis. Eur J Clin Microbiol Infect Dis. 2012; 31: $379-388$.

28. Yun PL, Decarlo AA, Hunter N. Gingipains of Porphyromonas gingivalis modulate leukocyte adhesion molecule expression induced in human endothelial cells by Ligation of CD99. Infection and Immunity. 2006; 74(3): 1661 - 1672.

29. Gan YH. Host susceptibility factors to bacterial infections in type 2 diabetes. PLOS Pathogen Journal. 2013; 9(12): 1 - 3.

30. Syaify A. Pengaruh level HBA1C terhadap fungsi fagositosis neutrofil (PMN) pada penderita periodontitis diabetika. Majalah Kedokteran Gigi Indonesia. 2012; 19(2): 93 - 97.

31. Liu H, Cheng Z, Song W, Wu We, Zhou Z. Immunoproteomic to analysis the pathogenicity factors in leukopenia caused by Klebsiella pneumonia bacteremia. PLoS ONE Journal. 2014; 9(10): $1-5$.

32. Iskander KN, Osuchowski MF, Stearns-Kurosawa DJ, Kurosawa S, Stepien D, Valentine C, Remick DG. Sepsis: multiple abnormalities, heterogenous responses, and evolving understanding. American Physiological Society. 2013; 93(3): 1247 - 1288.

33. Laszlo I, Trasy D, Molnar Z, Fazakas J. Review article sepsis: from pathophysiology to individualized patient care. Journal of Immunology Research. 2015; 2015: 1 - 14. 